\title{
Exilios de Medusa de Naín Nómez, o lanzar una PIEDRA AL FONDO DEL CORAZÓN
}

\section{Malú Urriola*}

Lorca decía en una carta escrita a su padre en 1920, que se nace poeta como se nace cojo, como se nace ciego, como se nace guapo. "Dejadme las alas en su sitio que yo os respondo que volaré bien", le respondía Lorca a su padre.

De Lorca aprendí que volar es viajar sin la piernas, no es sólo cuestión trasladarse sino, cruzar dimensiones literarias y de las otras, y ser tan valientes como para retar el antojo de los vientos. Por vientos me refiero a las convulsiones de las épocas. Escribir poesía es un ejercicio de otros mundos como sumergirse en el agua, pese que estamos hechos de ella. Escribir poesía es un ejercicio del que no se puede prescindir. $\mathrm{O}$ si se prescinde puede llevar a la muerte o al silencio que lo mismo. Una vez que se ha visto o escuchado emanar un poema, se quiere más. La poesía es una corriente del pensamiento desorganizador, una tarea solitaria que sólo puede ser experimentada como un acontecimiento. De pronto donde no había nada, el poema emana para poner en cuestión o en un punto de inflexión una pregunta poética que sólo el poeta será capaz de comprender aunque no la responda, lo demás son interpretaciones, lo demás es querer situar al poema, cosificarlo, dándole el sentido de un arte. Siempre he pensado que el aporte de la poesía a la escasa humanidad que la lee es la de levantar mundos nuevos y al mismo tiempo repensar los viejos. Levantar preguntas que la filosofía se esmera en responder. No es raro entonces, que Naím Nómez, quien estudió filosofía como primera elección de formación, sea también poeta y al mismo tiempo un fino lector de poesía.

En la Retórica especulativa de Pascal Quignard, hay un momento literario que no he podido olvidar: Cuando una sociedad está a la espera del acontecimiento que puede extinguirla, cuando el miedo, el desamparo, la pobreza, la desherencia y la envidia de todos contra todos

* Poeta y guionista. Santiago, Chile. maluurriola@gmail.com 
han llegado a un estado de madurez, comparable al de los frutos bajo el calor, una expresión secreta y ávida aparece en la mayoría de los rasgos de los vivos que se encuentran por las calles de las ciudades que son las nuevas selvas. Los rostros que nos rodean cargan con esa tristeza y manifiestan ese silencio que se extiende. Ese silencio a pesar de la Historia, es decir, a causa del mito de la Historia, sigue siendo ignorante de su ferocia. Las sociedades occidentales están de nuevo en ese estado de terrible madurez. Están en el límite de la carnicería.

Cito este breve texto de Quignard, que me remite como el eco de las montañas mistralianas también a Todorov y "el problema del Otro", a Rimbaud y "yo es otro" de las Cartas del vidente. "No debería decir pienso -versa Rimbaud- sino me piensan". Para Rimbaud las visiones son generadoras y desorganizadoras de sentidos. Qué se hace cuando se desorganiza el sentido o cuando se sucumbe a tornar la voz de una exiliada siendo el poeta hombre en este caso, sino desorganizar el sentido. Tomar la voz del débil, del subordinado, del castigado, del exiliado del poder.

Nómez trabaja y teje muchos hilos en Exilios de Medusa tornando la voz no sólo en varios hablantes: la principal, una voz femenina, la voz de Medusa, porque Medusa fue dentro de la mitología griega un monstruo femenino signado como mortal, en el amplio sentido de la palabra.

Compete acá también detenerse en la alteridad de la monstruosidad, eso otro que fue humano o ha nacido inhumano, o por inhumano se esconde y castiga, confinado al inframundo. Lo que está más allá de lo que los ojos pueden ver y, en el caso de Medusa, detener el ojo justamente sobre la mirada de ese otro puede poner en riesgo la vida de un sistema, de un orden, de un poder. Ese mirar conlleva el riesgo de perder la vida. Y mirar desde los ojos de Medusa porta la maldición y el riesgo de matar lo que se mira. De petrificarlo. Convertirlo en piedra. Lo humano convertido es piedra es una estatua. Esas que vemos cuando transitamos la ciudad. Esas, que pocas gentes saben a quien o qué representan, y las palomas no respetan.

Cuando se piensa en la mirada se piensa en la poesía. La poesía porta el ojo que puede ver y convertir en piedra, en un objeto natural de elevada consistencia y de la que está conformada en parte el planeta o el "mundo" que habitamos como seres humanos y vuelvo a Todorov, 
inhumanos también. Visitamos un mundo que contiene inframundos y que no ha dejado de tenerlos.

Naín Nómez sitúa dos lugares, o dos mundos alternos: exilio y agua.

El agua es todo... dice Medusa, la Medusa de Nómez. Así comienza este viaje a la revisión y reinvención de un mito, un pasado, un presente, un futuro, a "otra construcción" de una condena destinada desde la antigüedad sobre el sujeto femenino como el anverso y reverso de una moneda: la Gorgona humana, monstruo femenino del inframundo que tiene el poder de proteger (maternidad) y el peligro por la que se la ha castigado, de matar al hombre. La Medusa es la representación del rival femenino que más vale mantener subordinado a la protección. Por ello tal vez, cuando Perseo le corta la cabeza, se la lleva Atenea que la pone en su escudo.

Un aspecto interesante y no menor, es que en el caso de Medusa la humana, su poder reside en su cabeza, no en su belleza. Aunque Píndaro y Ovidio hayan cantado a su belleza. Su piel escamosa de serpiente (ya sabemos que la serpiente ha sido significada como la traición, la tentación, la portadora de un veneno que puede matar y pese a que se describe a las gorgonas con feroces dientes) no reside en su boca el peligro, sino en su cabeza. Es su cabeza la monstruosa. La que puede hechizar, enamorar y matar con su sola mirada. O la mirada de las serpientes, su cabellera.

Naín Nómez, nos propone como toda buena poesía que se piensa a si misma y piensa su época, un viaje, pero no el viaje del héroe, sino el de la anti heroína, la que sufre las intrigas y alevosía del poder en la ausencia del héroe masculino, en este caso el dios Poseidón que luego de ultrajarla desaparece del relato de esta historia como la mayoría de los abusadores.

Acompañamos en este viaje a otra Medusa, finamente leída y reescrita por Nómez, a uno de los menos deseados viajes, el del exilio donde nos encontraremos cara a casa con esa cabeza que se piensa y es pensada por otro, y otros, sus antagonistas, la diosa Atenea y el semi dios Perseo, hijo de Danae, que fue sacado de la escena amorosa por Polidectes su padrastro adoptivo que se había enamorado de su madre, y lo envió a donde las mismas palabras de Perseo lo destinaron por deseo al poder, a matar a Medusa. A enfrentarse a aquel rostro que sería mejor no ver.

Un rostro que nos resitúa en la materialidad de la que estamos hechos, de piedra y agua. Pero que también devuelve el poder de la cabeza a la 
mujer. La poesía de Nómez ejecuta además, un juego meta poético, y reflexiona sobre los límites del lenguaje, retoma a la hermosa Medusa de Ovidio o Píndaro, otorgándole esta vez el sueño del amor. Y aquí no puedo dejar de obviar la frase de la escritora, escultora y feminista Kate Millet, en una entrevista dada al diario El País en 1984, donde indica que: "El amor ha sido el opio de las mujeres, como la religión el de las masas. Mientras nosotras amábamos, los hombres gobernaban. Tal vez no se trate de que el amor en sí sea malo, sino de la manera en que se empleó para engatusar a la mujer y hacerla dependiente, en todos los sentidos. Entre seres libres es otra cosa".

¿Será ese deseo de amor mujeril, del que se vanaglorian y ensalzan las antifeministas, que el poeta pone como deseo en Medusa, el que tal vez la conduce a su muerte en este bello poema de Nómez"? No lo sé con exactitud, pero puedo olerlo.

Nómez escribe una historia poética y luego retrocede en sus "Marginalias". Escribe con una mano lo que borra con la otra. Cito una que me parece relevante para mi lectura, que por cierto, puede, como todo ejercicio de lectura y escritura, ser tan solo una cita con la incertidumbre y con el misterio poético Lorquiano: "No puedo decir otra cosa [escribe Nómez] este es tu destino en el mundo humano. Te lo advertimos páginas atrás (El coro griego) Puta o virgen, pero no sacerdotisa o etérea naraide, pero no bruja ni machi, pero no musa romanticona. No nos engañemos. Estamos en el neoliberalismo y no consumimos metaforones trasnochados ni historietas pasadas de moda" (58).

Sea como sea, esta Medusa en el exilio lapidará nuestro corazón como un reflejo de la poesía en el escudo de Perseo, que ha sido condenada al tormento poético de acontecer para ojos ciegos. La poesía también se ha pensado en el sueño -recordemos a los surrealistas- y será en ese otro mundo, donde la mata Perseo.

Quién podría librarse de Medusa sino un ciego... y aquí quiero también mencionar a Homero; no me voy a detener en él, ni en la escuela de poetas, ni en el mito de si fue un escritor o varios, sino en la ceguera y prefiero retomar una frase del prólogo que escribe Eugenia Brito a este libro: "El otro aquí es un impulso ciego a ser".

Y el amor en este caso, o el relato de la ausencia del amor, más que leerlo literalmente como el sentimiento que une a ese marino que ama 
a Medusa y que habla también en este poema, prefiero retomar a Brito y detenerme en ese impulso ciego que une para fatalidad, lo humano y lo inhumano, entendiéndose por inhumano al humano fragmentado, al humano neoliberal que como versa Nómez, ha sido construido por un deseo sin límites, que, al mismo tiempo persiste en unirse o perderse en otro, también fragmentado.

Escribe Nómez en una de sus "Marginalias": "Incestuosa y siempre enamorada Esmirna, Pandora, Atalanta...", y vuelvo a pensar si cumple su rol de nota al margen de su propia construcción poética o su rol de coro griego (que sacado del género dramático y puesto en la poesía no sólo cumple con la función de dar cuenta del contexto de la tragedia) ya que aparece como otras voces presenciales, a veces plurales, a veces singulares, de la construcción del discurso poético.

En otra de las "Marginalias" de este libro, Nómez el poeta, pregunta "¿de qué hablan? ¿Historias griegas, orientales, latinoamericanas?”. Al hablar de historias hace referencia a la tragedia. Cierto, la vida de una mujer ultrajada, expulsada y a la que le cortan la cabeza por poder, es la historia de cualquier mujer, en cualquier parte del orbe y de la historia de la humanidad o tal vez debiera decir de la historia de la inhumanidad.

El poeta interroga a sus hablantes líricos: ."...hay que explorar, explorar, hasta llegar a los límites". Pero después, otra Marginalia habla en singular y dice querer salirse de las metáforas de la historia.

Medusa es finalmente escrita por Nómez como la protectora que no pudo protegerse a sí misma del poder del patriarcado, ultrajada por el dios Poseidón y castigada por la diosa patriarca. Condenada a la muerte por un dictador y asesinada por un hombre -Perseo- que deseaba conseguir el poder a cambio de su cabeza.

Exilios de Medusa está hilado con vigorosos, acertados y hermosos versos, en el sentido de proporcionados y cargados de sentido, poderosas imágenes y conmovedoras escenas. El poema cuenta con la cadencia de una embarcación que cruza hablantes y géneros literarios. Es un poema y al mismo tiempo una historia poética que se retrotrae, se escribe y reescribe como las olas del mar reescriben la orilla. Se abre y se cierra como una flor del aire, cuyas raíces se enredan en los vientos de la poesía y en el agua, el origen. 
El poema como Medusa tiene el poder de convertir en piedra a quién la mire a los ojos y dejarnos esculpidos, eternizados o escritos en piedra, prolongados más allá de la insaciable hambre del tiempo que carcome incluso, las invenciones humanas como la escritura.

Escribir poesía en los tiempos de la ferocidad neoliberal, cuando el patriarcado como sistema político, social y religioso ha exacerbado su odio a las mujeres y los niños, puede parecer tal vez un gesto atolondrado, quimérico, pero la buena poesía siempre ha sido política y fijo la mirada en los versos finales: "Una mezcla de pavor, exaltación, angustia, una rémora desesperada seguir existiendo", versa Nómez y no puedo sino estar de acuerdo. 